\title{
The Effect of Banana Fiber and Banana Peel Fiber on the Chemical and Rheological Properties of Symbiotic Yogurt Made from Camel Milk
}

\author{
Younes Safdari $\left(\mathbb{D}\right.$, Mohsen Vazifedoost $\mathbb{D}$, Zohreh Didar $\mathbb{D}^{D}$, and Bahareh Hajirostamloo \\ Department of Food Science and Technology, Neyshabur Branch, Islamic Azad University, Neyshabur, Iran \\ Correspondence should be addressed to Mohsen Vazifedoost; m.vazifedoost@iau-neyshabur.ac.ir
}

Received 19 June 2021; Revised 2 October 2021; Accepted 30 November 2021; Published 15 December 2021

Academic Editor: Ivan Salmerón

Copyright (C) 2021 Younes Safdari et al. This is an open access article distributed under the Creative Commons Attribution License, which permits unrestricted use, distribution, and reproduction in any medium, provided the original work is properly cited.

\begin{abstract}
Functional foods play an important role in human health by prevention of disease. A variety of functional foods are produced around the world. Recently, the consumption of dairy products containing probiotic bacteria and prebiotics (synbiotic) has increased. Yoghurt is the most common fermented dairy product. Various compounds are used to enrich yoghurt. One of these compounds is dietary fiber. Since the peel of fruits has a significant amount of fiber and is mainly disposed of as solid waste, so using the peel of fruits to extract fiber can not only solve environmental problems but also produce a cheap and useful source that leads to the production of dietary fiber. In this study, the effect of banana fiber and banana peel fiber at different concentrations $(0,0.2,0.5$, and $1 \%)$ on the chemical and rheological properties of synbiotic yogurt prepared from camel milk was investigated. The result showed that with increase of the amount of both fibers, $\mathrm{pH}$, hydration, surface tension, overall acceptability, color, and flavor of the samples decreased significantly, but the viscosity, survival of probiotic bacteria (Lactobacillus casei and Lactobacillus gasseri), and texture acceptance increased significantly $(p<0.05)$. In conclusion, these fibers were able to reduce the syneresis of yogurt, which is one of the biggest disadvantages of yogurt, and help to increase health.
\end{abstract}

\section{Introduction}

In recent years, the consumption of functional products that protect humans against stress and various diseases has increased. Dairy products, especially yogurt, due to their rich composition of protein, essential fatty acids, and minerals such as calcium and phosphorus are considered as important human diet. One of the methods of producing functional foods is the use of probiotics which include Lactobacillus and Bifidobacterium in food products [1,2]. Probiotics have a great effect on the body's function, which can reduce blood cholesterol and prevent intestinal diseases, is an anticancer, and can improve the function of the gastrointestinal tract and immune system. For probiotics to be effective, their number must be at least $10^{6}$ to $10^{8} \mathrm{CFU}[3]$.

Synbiotic yogurt contains both probiotic and prebiotic agents simultaneously [4]. Prebiotics increases the number of probiotics by stimulating growth or increasing metabolic activity. For example, adding inulin to fermented milk maintains the population of bifidobacteria during the shelf life of the product [5].

Fibers are among the "prebiotic compounds" that are mainly supplied from the cell wall of fruits, vegetables, and grains and include polysaccharides, oligosaccharides, and lignin. Banana peel makes up about $40 \%$ of all fresh fruit, which is considered a good source of food antioxidants against 
cancer and heart disease, but it is disposed of as waste at a high cost $[6,7]$.

Due to the positive effects of banana peel fiber, its use can lead to higher consumption of products such as yogurt, which can help with a lack of fiber in the diet. Dairy products can be a suitable carrier for fiber. Some researchers have been reporting the use of fiber in dairy products. According to researches, increasing fiber reduces the sensory properties of the final product [8].

Extensive studies have been conducted on the milk of animals such as buffalo, sheep, goat, and camel and its nutritional effects [9-11]. Camel milk has been considered as a rich source of protein (2.5-9.2\%) and unsaturated fatty acids (43\%). Camel milk compared to cow's milk has 5 times potassium and vitamin C, 4 times more sodium, 3 times more calcium and magnesium, and more unsaturated fatty acids, chlorine, folic acid, and lactoferrin protein $[12,13]$. Camel milk is lower in fat and lactose than cow's milk and contains insulin-like substances, so it is a good choice for diabetics [14].

Camel milk has been suggested as an alternative for children who are allergic to cow's milk. Camel milk proteins also lack alpha-S casein and beta-lactoglobulin, while cow's milk contains a high percentage of both compounds. Camel milk has anticancer, antitumor, antiallergic, antidiabetic, antiviral, and antibacterial effects due to compounds such as lysozyme, lactoferrin, and insulin-like proteins that are resistant to gastric acidity and lactoperoxidase. Camel milk reduces oxidative stress and partially cures autism as well as other neurological diseases by increasing serum levels of glutathione, superoxide dismutase, and myeloperoxidase. In addition, it reduces cholesterol, due to the presence of protein-derived peptides [15].

Therefore, due to the biological compounds in camel milk and its beneficial effects on health, people are advised to consume milk and its fermented products. The purpose of the present study was the investigation the effect of banana fiber and banana peel fiber at different concentrations $(0,0.2,0.5$, and $1 \%)$ on chemical and rheological properties of synbiotic yogurt prepared from camel milk.

\section{Material and Methods}

2.1. Material. The camel milk was purchased from the Faculty of Veterinary Medicine (Ferdowsi University of Mashhad, Iran). The starter powder of DVS (Chr Hansen, ABY-10, Denmark), containing Lactobacillus delbrueckii subspecies Lactobacillus bulgaricus and Streptococcus thermophilus, and commercial probiotic starter (Lactobacillus casei and Lactobacillus gasseri) were purchased from the Kristin Hansen Company (Denmark). All chemicals were purchased from Merck (Germany).

2.2. Banana Fiber Extraction. Banana fruit was prepared from the local market (Neyshabur province, Iran). After peeling, it is cut into smaller pieces and dried in an oven (Parsion Teb, Iran) at $103^{\circ} \mathrm{C}$. Then, it was ground using a grinder, and powder was kept in polyethylene containers at $25^{\circ} \mathrm{C}$.

To extract fiber, $3 \mathrm{~g}$ of dried powder sample mixed with distilled water in a hot water bath at 60,75 , and $90^{\circ} \mathrm{C}$ was stirred and heated by a magnetic stirrer (Topolino, IKA, Germany) for 50, 100, and 150 minutes. Next, the samples were filtered twice, and a centrifuge (Hermle Labortechnik GMBA, Z206A, Germany) was used at $4000 \mathrm{rpm}$ for 20 minutes to separate the suspended particles. After centrifugation, to separate the solid particles from the liquid supernatant extract, it was passed through filter paper no. 41. The fiber-containing extract was placed in the refrigerator and mixed with $96 \%$ ethanol with a ratio of $1: 2$. The fiber was separated from the liquid by centrifugation at $4000 \mathrm{rpm}$ for 15 minutes. The supernatant was removed, and the remaining precipitate was washed with $70 \%$ ethanol and then with $96 \%$ ethanol to remove impurities. Finally, the samples were dried by freeze-drying and packaged in polyethylene bags and stored in the refrigerator [16].

\subsection{Fiber Properties}

2.3.1. Swelling. To calculate swelling, $0.2 \mathrm{~g}$ of the sample in a $10 \mathrm{ml}$ container was mixed with distilled water. After 12 hours, the swollen sample volume was read and the swelling was expressed in $\mathrm{ml} / \mathrm{g}$ [17].

2.3.2. Water Holding Capacity (WHC). 1-2 g of dietary fiber was weighed and transferred to a centrifuge tube. $30 \mathrm{ml}$ of distilled water was added to the contents of the centrifuge tube and allowed to stand for one hour. Then, it was transferred to a centrifuge of $2000 \mathrm{~g}$ for 15 minutes. The contents of the centrifuge tube were then carefully weighed, and WHC was measured using following formula [18]:

$$
\mathrm{WHC}=\frac{\text { wet weight }- \text { dry weight }}{\text { dry weight }} \text {. }
$$

2.4. Camel Milk Characteristics. Total dry matter was measured by oven at $105^{\circ} \mathrm{C}$. The protein content was measured using the Kjeldahl method according to AOAC methods. Ash measurement was performed using the AOAC method [19]. The fat content of the samples was determined by the Gerber volumetric method using a butyrometer [20].

2.5. Preparing Synbiotic Yogurt. To produce synbiotic yogurt made from camel milk, banana fiber and peel banana fiber were added to camel milk in 4 concentrations $(0,0.2,0.5$, and $1 \%)$. After homogenization of the mixture by UltraTrax at $9000 \mathrm{rpm}$, the thermal process was performed at $95^{\circ} \mathrm{C}$ by steam bath for 5 minutes. Subsequently, the milk temperature was reduced to the inoculation temperature $\left(45^{\circ} \mathrm{C}\right)$. Then, $0.1 \%$ of DVS powder containing a mixture of yogurt starter bacteria and probiotics (Lactobacillus casei and Lactobacillus Gasseri) was added. Afterward, the samples were kept in the incubator at $42^{\circ} \mathrm{C}$ for fermentation until the $\mathrm{pH}$ of the yogurt reached 4.5-6.6. The samples were then transferred to the refrigerator at $4^{\circ} \mathrm{C}$ and stored until all tests were performed [21].

\subsection{Synbiotic Yogurt Properties}

2.6.1. Syneresis. About $30 \mathrm{~g}$ of the sample was weighed into a $50 \mathrm{ml}$ falcon, and then, the tubes were centrifuged at $2500 \mathrm{rpm}$ for 10 minutes. After centrifugation, the released 
serum was weighed and the syneresis was calculated from the following equation [21]:

Syneresis $=$ weight of the whey after filtration/weight of the yogurt sample $) \times 100$.

2.6.2. $p H$. The $\mathrm{pH}$ of the samples was measured using a digital $\mathrm{pH}$ meter (Metrohm 827, Switzerland) at $25^{\circ} \mathrm{C}$. The $\mathrm{pH}$ meter was calibrated using buffer solutions of $\mathrm{pH} 7$ and 4 [21].

2.6.3. Rheological Properties. The viscosity of the samples was measured using a rotation viscometer (Brookfield DVIII Ultra, model RV, USA) at $25^{\circ} \mathrm{C}$ and shear rate range of 0 to $85 \mathrm{~S}^{-1}$ [21].

2.6.4. Interfacial Tension. The interfacial tension of the samples was measured using the ring method by a tensiometer (KRUSS, MK 100, Germany) equipped with an electric temperature regulation system at $25^{\circ} \mathrm{C}$.

2.6.5. Sensory Evaluation. The organoleptic properties of synbiotic yogurt samples (i.e., color, aroma, texture, taste, and overall acceptability) were evaluated using the hedonic method by 6 panelists ( 1 male and 5 female) in three replications.

2.6.6. Survival of Probiotic Bacteria in Yogurt. MRS agar medium (Mirmidia, Iran) containing $0.05 \%$ of bile salt was used to count the probiotic bacteria. The peptone water solution was also used for dilution. To prepare a dilution of 0.1 , $1 \mathrm{~g}$ of sample was mixed with $9 \mathrm{ml}$ of Peptone Water solution and mixed completely. Similarly, subsequent dilutions were prepared by transferring $1 \mathrm{ml}$ of each dilution to $9 \mathrm{ml}$ of peptone water solution. Lactobacillus casei and Lactobacillus gasseri were counted. The plates were incubated under aerobic and anaerobic conditions at $37^{\circ} \mathrm{C}$ for 72 hours. Anaerobic conditions were created using an anaerobic jar [21].

2.7. Statistical Analysis. The results were analyzed in a factorial design based on a completely randomized design using SPSS software (version 24). The mean values were analyzed using Duncan's test at 5\% $(p<0.05)$.

\section{Results and Discussion}

3.1. Chemical Compounds of Camel Milk. The main chemical constituents of the camel milk sample contained $4.27 \%$ fat, $3.37 \%$ protein, $7.56 \%$ dry matter, and $\mathrm{pH}$ of 6.34 , which was according to the values reported in other studies [22].

3.2. Physical Properties of Banana Fiber and Banana Peel Fiber. The rate of swelling of banana fiber and its peel was approximately $5.8 \mathrm{ml} / \mathrm{g}$. These results were similar to the swelling of wheat and pear fiber. Figuerola et al. [23] reported a range of 6.8-1.6 for grape fiber, apples, lemons, and oranges.

The water holding capacity (WHC) of banana fiber was significantly higher than banana peel fiber (2.80 and 2.66, respectively), which could be due to the presence of higher amounts of soluble dietary fiber and protein in the banana fiber. Soluble dietary fiber and protein have hydrophilic groups that increase water absorption.

\subsection{The Physicochemical Properties of Synbiotic Yoghurt}

3.3.1. $p H$. Table 1 shows the effect of different amounts of banana fiber on $\mathrm{pH}$ changes in yogurt samples. As can be seen, with increase of the banana fiber and banana peel fiber, the $\mathrm{pH}$ of yogurt samples decreased significantly $(p<0.001)$.

The results showed that in all samples, the $\mathrm{pH}$ decreased compared to the control sample. With the increase of banana fiber and banana peel fiber, the $\mathrm{pH}$ decreased. The lowest $\mathrm{pH}$ of the sample was related to the $1 \%$ fiber and the highest $\mathrm{pH}$ was related to the control sample. The reason for the decreasing $\mathrm{pH}$ with increasing fiber may be related to the prebiotic effect of fiber on improving the activity and growth of probiotic bacteria, which has been previously reported [21]. In other words, by increasing the activity of probiotic bacteria, the production of acidic metabolites resulting from their activity has increased, which can play a role in reducing the final $\mathrm{pH}$ of the product.

Another reason for the decrease in $\mathrm{pH}$ is increasing the dry matter of the product with the addition of fiber. This can increase the acidity and decrease the $\mathrm{pH}$.

Salwa et al. [24] reported that yogurt containing carrot extract has a lower $\mathrm{pH}$ than control yogurt due to its organic acids as well as sugar fermentation and acid production due to bacterial activity. Also, the results of this study were consistent with the results of Bonczar et al. [25], Tseng and Zhao [26], and Temiz et al. [27].

3.3.2. Syneresis. Table 2 shows the effect of different amounts of banana fiber on the syneresis of yogurt samples. As can be seen, the increase in banana fiber and banana peel fiber significantly reduced the synthesis of synbiotic yogurt samples $(p<0.001)$. In both types of fiber, synbiotic yogurt samples with $1 \%$ fiber had the lowest syneresis rate $(21.52 \%)$, and the control sample had the highest rate $(30.74 \%)$.

Staffolo et al. [28] concluded that yogurt containing apple fiber and orange fiber had less syneresis. The ability of fibers to bind to water molecules and interfere with milk components, especially proteins, and thus the stability of the protein network can prevent the free movement of water and lead to a reduction in syneresis. Żbikowska et al. [29] showed that the use of inulin reduces the syneresis of yogurt and other fermented milks. Another reason for reducing the syneresis of yogurt containing prebiotics is increasing the consistency and also the capacity index of the complex with 
TABLE 1: The effect of banana fiber on $\mathrm{pH}$ changes in yogurt samples.

\begin{tabular}{lcccc}
\hline Treatment & 0 & \multicolumn{3}{c}{ Concentrations (\%) } \\
\hline Banana fiber & $4.37 \pm 0.01^{\mathrm{bB}}$ & $4.38 \pm 0.01^{\mathrm{abB}}$ & $4.41 \pm 0.01^{\mathrm{aA}}$ & $4.40 \pm 0.01^{\mathrm{aA}}$ \\
Banana peel fiber & $4.42 \pm 0.01^{\mathrm{aA}}$ & $4.40 \pm 0.01^{\mathrm{abA}}$ & $4.39 \pm 0.01^{\mathrm{bcB}}$ & $4.37 \pm 0.01^{\mathrm{cB}}$ \\
\hline
\end{tabular}

The mean \pm SD (standard deviation) within columns with different capital letters and rows with different small letters differs significantly $(p<0.05)$.

TABLE 2: The effect of banana fiber on syneresis changes in yogurt samples.

\begin{tabular}{lcccc}
\hline \multirow{2}{*}{ Treatment } & 0 & \multicolumn{2}{c}{ Concentrations (\%) } & 0.5 \\
\hline Banana fiber & $29.16 \pm 1.04^{\mathrm{aA}}$ & $28.00 \pm 1.00^{\mathrm{abA}}$ & $26.33 \pm 1.15^{\mathrm{beA}}$ & $24.00 \pm 1.001^{\mathrm{cA}}$ \\
Banana peel fiber & $28.20 \pm 0.70^{\mathrm{aA}}$ & $27.00 \pm 0.50^{\mathrm{abA}}$ & $26.00 \pm 0.60^{\mathrm{bcA}}$ & $25.10 \pm 0.80^{\mathrm{cA}}$ \\
\hline
\end{tabular}

The mean \pm SD (standard deviation) within columns with different capital letters and rows with different small letters differs significantly $(p<0.05)$.

water, which allows prebiotic compounds to prevent syneresis by increasing the binding water.

Ramirez-Santiago et al. [30] also showed that enriched yogurt with potato fiber had less syneresis. Increasing the dry matter stabilizes the gel network and also increases the water binding capacity and reduces syneresis [31].

In this study, the water holding capacity of yogurt samples is more affected by the hydrocolloids. Increasing the amount of hydrocolloid increases the amount of water trapped in the gel network. However, with a further increase in the percentage of hydrocolloids, the gel structure is destroyed and its water holding capacity decreases [32].

Also, Gustaw et al. [21] used prebiotics including fructooligosaccharide, inulin, and resistant starch in yogurt and concluded that yogurt samples containing fructooligosaccharide and inulin had lower viscosity, lower firmness, and comparatively lower syneresis.

3.3.3. Rheological Properties. Table 3 shows the effect of different amounts of banana fiber on the viscosity of yogurt samples. As can be seen, the increase in banana fiber and banana peel fiber significantly increased the apparent viscosity of synbiotic yogurt samples $(p<0.001)$. The highest viscosity was related to the $1 \%$ banana fiber samples, and the lowest viscosity was related to the control sample.

The fiber in yogurt samples changes its structure, strengthens the gel structure, and improves the rheological behaviors by binding to water molecules [33]. These results are in agreement with the results of other research. Increasing the water binding capacity and creating a stronger gel increases the resistance to flow. Increasing the total solid can also increase the viscosity [21].

The fiber increases the viscosity and firmness of the yoghurt. The increase in viscosity of low-fat yogurt containing soy flour may be related to the interaction between fiber, oligo- or polysaccharides, and low-fat yogurt proteins [3].

3.3.4. Interfacial Tension. Table 4 shows the effect of different amounts of banana fiber on the surface tension of yogurt samples. As can be seen, the increase in banana fiber and banana peel fiber significantly reduced the surface tension of synbiotic yogurt samples $(p<0.001)$.

However, no significant difference was observed between the control sample and $0.2 \%$ banana fiber $(p>0.05)$, but there was a significant difference between the other samples $(p<0.05)$. The highest and lowest surface tensions were related to the control sample and $1 \%$ banana fiber sample, respectively.

3.3.5. Sensory Evaluation. Table 5 shows the effect of banana fiber on the sensory properties of synbiotic yogurt samples.

As can be seen, with increasing fiber content, the color of yogurt samples significantly decreased compared to that of the control sample $(p<0.001)$. The highest color was related to the control sample, and the lowest was related to the $1 \%$ banana fiber sample. Also, no significant difference was observed between the control treatments and $0.2 \%$ banana fiber. As the amount of fiber increases, the amount of syneresis decreases, and due to the change in light reflection, the opacity of the product also increases.

Increasing the banana fiber caused a significant increase in the consistency of yogurt samples $(p<0.001)$.

Overall acceptance of the product showed a significant decrease with increasing amount of banana fiber $(p<0.001)$. The lowest and the highest overall acceptability were obtained for the sample containing $1 \%$ fiber and the control treatment, respectively.

Staffolo et al. [28] showed that an increase of $1.3 \%$ in fiber had no effect on sensory properties, but increasing this value caused a significant sensory decrease. Sendra et al. [33] also showed that the increase in fiber caused a significant reduction in sensory properties, which is consistent with the results of this study.

Some studies have shown that prebiotics in the probiotic yoghurt cause improvement of the texture of the product; however, over time, as the production of acid increases and the $\mathrm{pH}$ decreases, the sensory properties of the final product decrease. Similar findings have been reported previously [34-36]. 
TABLE 3: The effect of banana fiber on viscosity of yogurt samples.

\begin{tabular}{lcccc}
\hline Treatment & 0 & 0.2 & Concentrations (\%) & 0.5 \\
\hline Banana fiber & $2650 \pm 250^{\mathrm{cA}}$ & $3100 \pm 100^{\mathrm{bA}}$ & $3250 \pm 50^{\mathrm{abA}}$ & $3516 \pm 175^{\mathrm{aA}}$ \\
Banana peel fiber & $3000 \pm 300^{\mathrm{bA}}$ & $2800 \pm 100^{\mathrm{bB}}$ & $3150 \pm 150^{\mathrm{bA}}$ & $3600 \pm 200^{\mathrm{aA}}$ \\
\hline
\end{tabular}

The mean \pm SD (standard deviation) within columns with different capital letters and rows with different small letters differs significantly $(p<0.05)$.

TABLE 4: The effect of banana fiber on interfacial tension of yogurt samples.

\begin{tabular}{lcccc}
\hline \multirow{2}{*}{ Treatment } & 0 & \multicolumn{3}{c}{ Concentrations (\%) } \\
& 0.2 & $32.90 \pm 0.50^{\mathrm{aA}}$ & 1 \\
\hline Banana fiber & $33.60 \pm 1.5^{\mathrm{aA}}$ & $33.43 \pm 055^{\mathrm{aA}}$ & $31.50 \pm 0.50^{\mathrm{bA}}$ \\
Banana peel fiber & $35.16 \pm 1.76^{\mathrm{aA}}$ & $34.16 \pm 0.90^{\mathrm{aA}}$ & $31.33 \pm 0.86^{\mathrm{bA}}$ & $29.33 \pm 0.92^{\mathrm{bB}}$ \\
\hline
\end{tabular}

The mean \pm SD (standard deviation) within columns with different capital letters and rows with different small letters differs significantly $(p<0.05)$.

TABLE 5: The effect of banana fiber on sensory properties of yogurt samples.

\begin{tabular}{|c|c|c|c|c|c|}
\hline \multirow{2}{*}{ Sensory characteristic } & \multirow{2}{*}{ Treatment } & \multicolumn{4}{|c|}{ Concentrations (\%) } \\
\hline & & 0 & 0.2 & 0.5 & 1 \\
\hline \multirow{2}{*}{ Flavor } & Banana fiber & $4.5 \pm 0.55^{\mathrm{aA}}$ & $4.70 \pm 0.20^{\mathrm{abA}}$ & $4.80 \pm 0.20^{\mathrm{aA}}$ & $3.20 \pm 0.50^{\mathrm{aB}}$ \\
\hline & Banana peel fiber & $4.5 \pm 0.50^{\mathrm{aA}}$ & $4.20 \pm 0.20^{\mathrm{abB}}$ & $4.00 \pm 0.20^{\mathrm{abB}}$ & $3.40 \pm 0.30^{\mathrm{bA}}$ \\
\hline \multirow{2}{*}{ Texture } & Banana fiber & $4.20 \pm 0.10^{\mathrm{aA}}$ & $4.30 \pm 0.10^{\mathrm{aA}}$ & $4.45 \pm 0.15^{\mathrm{aA}}$ & $4.51 \pm 0.10^{\mathrm{bA}}$ \\
\hline & Banana peel fiber & $3.93 \pm 0.25^{\mathrm{bA}}$ & $4.10 \pm 0.30^{\mathrm{abA}}$ & $4.50 \pm 0.40^{\mathrm{abA}}$ & $4.86 \pm 0.40^{\mathrm{aA}}$ \\
\hline \multirow{2}{*}{ Color } & Banana fiber & $4.10 \pm 0.50^{\mathrm{aA}}$ & $3.80 \pm 0.30^{\mathrm{aA}}$ & $3.60 \pm 0.10^{\mathrm{aA}}$ & $3.23 \pm 0.25^{\mathrm{bA}}$ \\
\hline & Banana peel fiber & $4.5 \pm 0.50^{\mathrm{aA}}$ & $3.90 \pm 0.30^{\mathrm{bA}}$ & $3.5 \pm 0.20^{\mathrm{bA}}$ & $3.90 \pm 0.10^{\mathrm{bA}}$ \\
\hline \multirow{2}{*}{ Overall acceptability } & Banana fiber & $4.00 \pm 0.30^{\mathrm{aA}}$ & $4.03 \pm 0.11^{\mathrm{aA}}$ & $3.93 \pm 0.15^{\mathrm{aA}}$ & $3.36 \pm 0.15^{\mathrm{bA}}$ \\
\hline & Banana peel fiber & $4.50 \pm 0.30^{\mathrm{abA}}$ & $4.10 \pm 0.10^{\mathrm{abA}}$ & $3.60 \pm 0.30^{\mathrm{bcA}}$ & $3.20 \pm 0.20^{\mathrm{cA}}$ \\
\hline
\end{tabular}

The mean \pm SD (standard deviation) within columns with different capital letters and rows with different small letters differs significantly $(p<0.05)$.

TABLE 6: The effect of banana fiber on population of Lactobacillus casei and Lactobacillus gasseri in yogurt samples.

\begin{tabular}{lcccrr}
\hline \multirow{2}{*}{ MO } & Treatment & \multicolumn{3}{c}{ Concentrations (\%) } \\
& & 0 & 0.2 & 0.5 & 1 \\
\hline \multirow{2}{*}{ Lactobacillus casei } & Banana fiber & $7.23 \pm 0.35^{\mathrm{aA}}$ & $7.70 \pm 0.20^{\mathrm{abA}}$ & $7.80 \pm 0.20^{\mathrm{aA}}$ & $8.20 \pm 0.50^{\mathrm{aA}}$ \\
& Banana peel fiber & $7.00 \pm 0.50^{\mathrm{bA}}$ & $7.5 \pm 0.50^{\mathrm{abA}}$ & $8.00 \pm 0.20^{\mathrm{abA}}$ & $8.20 \pm 0.30^{\mathrm{aA}}$ \\
Lactobacillus gasseri & Banana fiber & $7.00 \pm 0.40^{\mathrm{bA}}$ & $7.35 \pm 0.15^{\mathrm{abA}}$ & $7.70 \pm 0.30^{\mathrm{aA}}$ & $7.80 \pm 0.20^{\mathrm{aA}}$ \\
& Banana peel fiber & $6.50 \pm 0.50^{\mathrm{bA}}$ & $6.76 \pm 0.25^{\mathrm{abA}}$ & $7.00 \pm 0.50^{\mathrm{abA}}$ & $7.80 \pm 0.30^{\mathrm{aA}}$ \\
\hline
\end{tabular}

The mean \pm SD (standard deviation) within columns with different capital letters and rows with different small letters differs significantly $(p<0.05)$.

3.3.6. Survival of Probiotic Bacteria in Yogurt. Table 6 shows the effect of different amounts of banana fiber on the population of Lactobacillus casei and Lactobacillus gasseri in yogurt samples. As can be seen, with increasing banana fiber and banana peel fiber, the survival of Lactobacillus casei and Lactobacillus gasseri increased significantly $(p<0.01)$.

As can be seen, the highest survival of Lactobacillus casei and Lactobacillus gasseri was for the sample of $1 \%$ banana fiber and the lowest was for the control sample. The survival of Lactobacillus casei and Lactobacillus gasseri can be attributed to the prebiotic compounds of banana fiber and its peel. Prebiotic compounds increase the growth and activity of probiotics.

Sendra et al. [33] claimed that the survival of probiotics due to the increase in fiber, the rapid conversion of lactose to lactic acid, and the interaction of the milk components (mainly proteins) stabilize the protein and prevent the transfer of free water.

Another reason for the increase in probiotics by increasing the amount of banana fiber is to increase the buffering capacity of the fibers, which protects the bacteria against stressful conditions [32]. The increase in survival of bacteria is also due to the increase of the food required by probiotic bacteria to provide nitrogen and carbon sources and suitable environmental conditions for further growth and activity of this microorganism.

\section{Conclusion}

Functional yogurt contains fiber has health effects on humans. In this study, the effects of the banana fiber and banana peel 
fiber on physicochemical, rheological, and sensory properties of synbiotic yogurt using camel milk and probiotic bacteria (Lactobacillus casei and Lactobacillus gasseri) were investigated. The banana fiber and banana peel fiber increased viscosity, the survival of probiotic bacteria, and consistency but decreased $\mathrm{pH}$, syneresis, surface tension, and sensory properties (color, flavor, and overall acceptability). In all samples, the effect of banana fiber was much greater than the peel fiber. It can be concluded that these two types of fiber can have healing properties for the body.

\section{Data Availability}

The data used to support the findings of this study are available from the corresponding author upon request.

\section{Conflicts of Interest}

There are no conflicts of interest.

\section{Acknowledgments}

We are grateful to the respected authorities of the research lab at Neyshabur Branch, Islamic Azad University, Neyshabur, Iran.

\section{References}

[1] F. Leroy and D. Vuystl, "Lactic acid bacteria as function starter cultures for the food fermentation industry," Trends in food Sciece \& Technogoge, vol. 15, no. 2, pp. 67-68, 2007.

[2] N. P. Shah, "Functional cultures and health benefits," International Dairy Journal, vol. 17, no. 11, pp. 1262-1277, 2007.

[3] O. N. Donkor, S. L. I. Nilmini, P. Stolic, T. Vasiljevic, and N. P. Shah, "Survival and activity of selected probiotic organisms in set-type yoghurt during cold storage," Journal, vol. 17, no. 6, pp. 657-665, 2007.

[4] L. C. Aragon-Alegro, J. H. Alarcon Alegro, H. Roberta Cardarelli, M. Chih Chiu, and S. M. Isay Saad, "Potentially probiotic and synbiotic chocolate mousse," LWT-Food Science and Technology., vol. 40, no. 4, pp. 669-675, 2007.

[5] J. Manning, R. Rastall, G. Gibson, S. Salminen, A. von Wright, and A. Ouwehand, "Prebiotics and lactic acid bacteria," Food Science and Technology-New York-Marcel Dekker, vol. 139, pp. 407-418, 2004.

[6] S. Someya, Y. Yoshiki, and K. Okubo, "Antioxidant compounds from bananas (Musa cavendish)," Food Chemistry, vol. 79, no. 3, pp. 351-354, 2002.

[7] P. Zhang, R. L. Whistler, J. N. BeMiller, and B. R. Hamaker, "Banana starch: production, physicochemical properties, and digestibility-a review," Carbohydrate Polymers, vol. 59, no. 4, pp. 443-458, 2005.

[8] H. D. Golf, Fiber-Enriched Dairy Products, Woodhead Publishing, 2013.

[9] A. Zouari, I. Mtibaa, M. Triki et al., "Effect of spray-drying parameters on the solubility and the bulk density of camel milk powder: a response surface methodology approach," International Journal of Dairy Technology, vol. 73, no. 3, pp. 616624, 2020.

[10] E. Hadjimbei, G. Botsaris, V. Goulas, E. Alexandri, V. Gekas, and I. P. Gerothanassis, "Functional stability of goats' milk yoghurt supplemented with Pistacia atlantica resin extracts and Saccharomyces boulardii," International Journal of Dairy Technology, vol. 73, no. 1, pp. 134-143, 2020.

[11] S. M. S. El-Shafei, S. S. Sakr, and N. H. I. Abou-Soliman, "The impact of supplementing goats' milk with quinoa extract on some properties of yoghurt," International Journal of Dairy Technology, vol. 73, no. 1, pp. 126-133, 2020.

[12] A. Kiai, A. Mn, and H. Samie Adab, "Antagonistic effect of lactic acid bacteria isolated from us against pathogenic bacteria," Journal of Gorgan University of Medical Sciences, vol. 8, pp. 28-33, 2006.

[13] M. Tajabadi, M. Ebrahimi, A. Hejazi, and A. Nouri, "Characterization of probiotic lactobacilli isolated from fermented dairy products Lighvan," Science Journal of Teach Training, vol. 4, pp. 941-952, 2007.

[14] R. Bromberg, I. Moreno, C. L. Zaganini, R. R. Delboni, and J. D. Oliveira, "Isolation of bacteriocin-producing lactic acid bacteria from meat and meat products and its spectrum of inhibitory activity," Brazilian Journal of Microbiology, vol. 35, no. 1-2, pp. 137-144, 2004.

[15] J. Norouzi, A. Khanafari, and N. Biglari, "Isolation and identification of lactic acid bacteria in their mouths and inhibitory effects on some pathogenic intestinal bacteria," World Journal of Microbiology, vol. 1, pp. 29-38, 2008.

[16] P. Chantaro, S. Devahastin, and N. Chiewchan, "Production of antioxidant high dietary fiber powder from carrot peels," Science and Technology, vol. 41, no. 10, pp. 1987-1994, 2008.

[17] J. A. Robertson, F. D. de Monredon, P. Dysseler, F. Guillon, R. Amado, and J. F. Thibault, "Hydration properties of dietary fibre and resistant starch: a European collaborative study," LWT-Food Science and Technology., vol. 33, no. 2, pp. 72-79, 2000.

[18] A. Pourfarzad, H. Mahdavian-Mehr, and N. Sedaghat, "Coffee silverskin as a source of dietary fiber in bread-making: optimization of chemical treatment using response surface methodology," LWT-Food Science and Technology, vol. 50, no. 2, pp. 599-606, 2013.

[19] AOAC, Official Methods of Analysis, Association of Official Analytical Chemists, Gaithersburg, MD, USA, 17th edition, 2000.

[20] H. Egan, R. S. Kirk, and R. Sawyer, Pearson's Chemical Analysis of Foods, Longman Scientific and Technical Bath Press, Avon, UK, 8th edition, 1981.

[21] W. Gustaw, M. Kordowska-Wiater, and J. Kozioł, "The influence of selected prebiotics on the growth of lactic acid bacteria for bioyoghurt production," Acta Scientiarum Polonorum Technologia Alimentaria, vol. 10, no. 4, pp. 455-466, 2011.

[22] I. B. Hashim, A. H. Khalil, and H. Habib, "Quality and acceptability of a set-type yogurt made from camel milk," Journal of Dairy Science, vol. 92, no. 3, pp. 857-862, 2009.

[23] F. Figuerola, M. L. Hurtado, A. M. Estévez, I. Chiffelle, and F. Asenjo, "Fibre concentrates from apple pomace and citrus peel as potential fibre sources for food enrichment," Food Chemistry, vol. 91, no. 3, pp. 395-401, 2005.

[24] A. Salwa, E. A. G. Aly, and A. E. Neimat, "Carrot yoghurt: sensory, chemical, microbiological properties and consumer acceptance," Pakistan Journal of Nutrition, vol. 3, no. 6, 2004.

[25] G. Bonczar, M. Wszolek, and A. Siuta, "The effects of certain factors on the properties of yoghurt made from ewe's milk," Food Chemistry, vol. 79, no. 1, pp. 85-91, 2002. 
[26] A. Tseng and Y. Zhao, "Wine grape pomace as antioxidant dietary fibre for enhancing nutritional value and improving storability of yogurt and salad dressing," Food Chemistry, vol. 138, no. 1, pp. 356-365, 2013.

[27] H. Temiz, Z. Tarakçi, T. Karadeniz, and T. Bak, "The effect of loquat fruit (Eriobotrya japonica) marmalade addition and storage time on phsico-chemical and sensory properties of yogurt," Journal of Agricultural Sciences, vol. 18, pp. 329$338,2012$.

[28] M. D. Staffolo, N. Bertola, M. Martino, and A. Bevilacqua, "Influence of dietary fiber addition on sensory and rheological properties of yogurt," International Dairy Journal, vol. 14, no. 3, pp. 263-268, 2004.

[29] A. Żbikowska, I. Szymańska, and M. Kowalska, "Impact of inulin addition on properties of natural yogurt," Applied Sciences, vol. 10, no. 12, p. 4317, 2020.

[30] C. Ramirez-Santiago, L. Ramos-Solis, C. Lobato-Calleros, C. Peña-Valdivia, E. J. Vernon-Carter, and J. Alvarez-Ramírez, "Enrichment of stirred yogurt with soluble dietary fiber from Pachyrhizus erosus L. urban: effect on syneresis, microstructure and rheological properties," Journal of Food Engineering, vol. 101, no. 3, pp. 229-235, 2010.

[31] P. Bierzuńska, D. Cais-Sokolińska, and A. Yiğit, "Storage stability of texture and sensory properties of yogurt with the addition of polymerized whey proteins," Food, vol. 8, no. 11, p. 548, 2019.

[32] F. Zare, J. I. Boye, V. Orsat, C. Champagne, and B. K. Simpson, "Microbial, physical and sensory properties of yogurt supplemented with lentil flour," Food Research International, vol. 44, no. 8, pp. 2482-2488, 2011.

[33] E. Sendra, V. Kuri, J. Fernández-López, E. Sayas-Barberá, C. Navarro, and J. A. Pérez-Alvarez, "Viscoelastic properties of orange fiber enriched yogurt as a function of fiber dose, size and thermal treatment," LWT-Food Science and Technology, vol. 43, no. 4, pp. 708-714, 2010.

[34] L. Hayward, E. Finlay, M. Lafortune et al., "Investigating the disclosure of ingredient lists impact on consumers' sensory perceptions of red wines produced in Nova Scotia, Canada," Journal of Sensory Studies, vol. 35, no. 6, article e12602, 2020.

[35] A. Shafi, H. Naeem Raja, U. Farooq et al., "Antimicrobial and antidiabetic potential of synbiotic fermented milk: a functional dairy product," International Journal of Dairy Technology, vol. 72, no. 1, pp. 15-22, 2019.

[36] L. C. Grom, R. S. Rocha, C. F. Balthazar et al., "Postprandial glycemia in healthy subjects: which probiotic dairy food is more adequate?," Journal of Dairy Science, vol. 103, no. 2, pp. 1110-1119, 2020. 